\title{
Impact of fertiliser nitrogen formulation, and $N$ stabilisers on nitrous oxide emissions in spring barley
}

Article

Accepted Version

Creative Commons: Attribution-Noncommercial-No Derivative Works 4.0

Roche, L., Forrestal, P. J., Lanigan, G. J., Richards, K. G., Shaw, L. J. and Wall, D. P. (2016) Impact of fertiliser nitrogen formulation, and $\mathrm{N}$ stabilisers on nitrous oxide emissions in spring barley. Agriculture, Ecosystems and Environment, 233. pp. 229-237. ISSN 0167-8809 doi:

https://doi.org/10.1016/j.agee.2016.08.031 Available at https://centaur.reading.ac.uk/66747/

It is advisable to refer to the publisher's version if you intend to cite from the work. See Guidance on citing.

To link to this article DOI: http://dx.doi.org/10.1016/j.agee.2016.08.031

Publisher: Elsevier

All outputs in CentAUR are protected by Intellectual Property Rights law, including copyright law. Copyright and IPR is retained by the creators or other copyright holders. Terms and conditions for use of this material are defined in the End User Agreement. 


\section{CentAUR}

Central Archive at the University of Reading

Reading's research outputs online 
1 Title: Impact of fertiliser nitrogen formulation, and $\mathbf{N}$ stabilisers on nitrous oxide

4 Authors: Roche, L., ${ }^{1,2}$ Forrestal, P.J., ${ }^{1}$ Lanigan, G.J., ${ }^{1}$ Richards, K.G., ${ }^{1}$ Shaw, L.J., ${ }^{2}$ Wall, 5 D.P. ${ }^{1}$ Corresponding authors, Lanigan, G.J. gary.lanigan@teagasc.ie and Wall, D.P. david.wall@teagasc.ie

7

8

\author{
Affiliations: \\ ${ }^{1}$ Teagasc Environment Research Centre, Johnstown Castle, Co.Wexford, Ireland. \\ ${ }^{2}$ Soil Research Centre, Department of Geography and Environmental Science, University of \\ Reading, UK.
}

\title{
Abstract
}

The application of nitrogen $(\mathrm{N})$ fertilisers to agricultural soils is a major source of nitrous oxide $\left(\mathrm{N}_{2} \mathrm{O}\right)$ emissions. The Intergovernmental Panel on Climate Change (IPCC) has set a default emission factor of $1 \%\left(\mathrm{EF}_{1}\right)$ for $\mathrm{N}$ fertiliser applied to managed agricultural soils. This value does not differentiate between different $\mathrm{N}$ fertiliser formulations or rates of $\mathrm{N}$ application. The objective of this field study under spring barley was to determine $\mathrm{N}_{2} \mathrm{O}$ EF's for different $\mathrm{N}$ fertiliser formulations including urea and urea stabilised with the nitrification inhibitor dicyandiamide (DCD) and/or the urease inhibitor $N$-(n-butyl) thiophosphoric triamide (NBPT) and to evaluate their $\mathrm{N}_{2} \mathrm{O}$ loss abatement potential relative to calcium ammonium nitrate $(\mathrm{CAN})$. The highest $\mathrm{EF}_{1}$ measured was $0.49 \%$ for $\mathrm{CAN}$ which was less than half the IPCC default value of $1 \%$. While the urease inhibitor did not reduce emissions relative to CAN; the nitrification inhibitor significantly reduced emissions compared to CAN with $\mathrm{EF}_{1}$ as low as $0.00 \%$ for a typical spring barley site. There was no significant impact of CAN or urea application rate on $\mathrm{EF}_{1}$ but there was a significant negative relationship 
27 observed for urea in 2013. The study highlights the importance of generating higher Tier 28 emission factors in terms of fertiliser type for use in national inventories.

29

30 Keywords: urea; emission factor; arable soil; DCD; Inhibitors; NBPT 31 


\section{Introduction}

33 Concentrations of atmospheric greenhouse gases (GHGs) have increased since the beginning of the industrial era, due to anthropogenic activities (U.S. EPA, 2015). Between 1990 and 2005, global non-carbon dioxide $\left(\mathrm{CO}_{2}\right)$ GHG emissions grew by $10 \%$ to approximately 10,800 megatons $\mathrm{CO}_{2}$ equivalent ( $\mathrm{Mt} \mathrm{CO}_{2}$ eq) and are expected to increase by $43 \%$ by 2030 (U.S. EPA, 2012). Globally, the agriculture sector accounts for the largest proportion of non$\mathrm{CO}_{2}$ GHG emissions, accounting for 54\% in 2005 (U.S. EPA, 2012). Nitrous oxide comprises approximately $32 \%$ of agricultural emissions (U.S. EPA, 2012) and is a potent GHG, with a global warming potential 265 times that of $\mathrm{CO}_{2}$ over a 100 year time frame (Myhre et al., 2013). The atmospheric concentration of $\mathrm{N}_{2} \mathrm{O}$ has increased at an average rate of $0.75 \mathrm{ppb}^{\mathrm{yr}^{-}}$ ${ }^{1}$, rising $20 \%$ since 1750 to $324 \mathrm{ppb}$ (IPCC, 2014). Emissions associated with nitrogen (N) application to agricultural soils comprise $60 \%$ of global $\mathrm{N}_{2} \mathrm{O}$ emissions and are projected to increase from 6.1 to over $7 \mathrm{Tg} \mathrm{N}_{2} \mathrm{O}-\mathrm{N} \mathrm{yr}^{-1}$ by 2030 , due to increased global population and food demand (Reay et al., 2012). The use of mineral fertilisers has been one of the principal drivers of this increase in emissions (Davidson, 2009). Excess $\mathrm{N}$ application has resulted in enhanced reactive $\mathrm{N}$ losses to the environment (Bell et al., 2015). Furthermore $\mathrm{N}_{2} \mathrm{O}$ is the single most important ozone-depleting gas and is expected to remain so throughout the $21^{\text {st }}$ century (Ravishankara et al., 2009).

In order to generate total $\mathrm{N}_{2} \mathrm{O}$ emissions for inputting into national inventories, the quantity of a given activity (e.g. tonnes of fertiliser applied) is multiplied by an emission factor (EF). This emission factor is defined as the percentage of $\mathrm{N}_{2} \mathrm{O}$ emitted as a proportion of the $\mathrm{N}$ applied. The IPCC default EF for direct $\mathrm{N}_{2} \mathrm{O}$ emissions, associated with the application of mineral or organic fertiliser to managed soils, (termed $\mathrm{EF}_{1}$ ) is $1 \%$ of the $\mathrm{N}$ applied (IPCC, 2006). This value is a crude estimate as it does not account for crop and soil type, climatic conditions or management practices, all of which affect $\mathrm{N}_{2} \mathrm{O}$ emissions (Dobbie and Smith, 

specific data would allow temperate regions to use the Tier 2 emission inventory methodology, where these more detailed and accurate emission factors that are specific for soil and crop type are required (IPCC, 2006). Subsequently, these data could support the development of new $\mathrm{N}$ fertiliser recommendations in Ireland; therefore promoting continued reductions of GHG emissions in line with the 2030 targets to reduce GHG emissions by $40 \%$ (EC, 2014).

In Ireland the agricultural sector contributes $32 \%$ of national GHG emissions (Duffy et al., 2015). Nitrogen application to agricultural soils is one of the key categories, accounting for $22 \%$ of total emissions from agriculture and this is projected to increase by $12 \%$ by 2020 (EPA, 2013). The focus of this study is on arable land, specifically examining the $\mathrm{N}_{2} \mathrm{O}$ emissions resulting from the addition of $\mathrm{N}$ fertiliser to spring cereal crops, which is one of the largest contributors to GHGs from this land use type. Altering fertiliser formulation and/or rate as well as the incorporation of inhibitors may be a key abatement strategy for reducing $\mathrm{N}_{2} \mathrm{O}$ emissions from agriculture (Harty et al., 2016).

Calcium ammonium nitrate (CAN) is the dominant $\mathrm{N}$ fertiliser used by arable farmers in Ireland. CAN contains $27 \% \mathrm{~N}$, of which $50 \%$ is in the nitrate-N form and immediately contributes to the soil nitrate pool. Nitrate is then available for $\mathrm{N}_{2} \mathrm{O}$ loss through the denitrification processes. Nitrification may also be an important source of $\mathrm{N}_{2} \mathrm{O}$ from the application of urea or ammonium based fertilisers (Bremner and Blackmer, 1978). Substituting CAN with urea as an alternative $\mathrm{N}$ fertiliser formulation has the potential to reduce direct $\mathrm{N}_{2} \mathrm{O}$ emissions, associated with denitrification, because urea or ammonium $\mathrm{N}$ forms are not immediately available for denitrification after application. However, there is potential for nitrifier denitrification to be a source of $\mathrm{N}_{2} \mathrm{O}$ (Kool et al., 2011) coupled with the

81 potential for urea to favour $\mathrm{N}$ loss as ammonia during urea hydrolysis. The addition of a 
urease inhibitor has potential to reduce ammonia volatilisation which not only contributes to air pollution but which can also contribute to indirect $\mathrm{N}_{2} \mathrm{O}$ emissions (Watson et al., 2009; Forrestal et al., 2015). The addition of a nitrification inhibitor has potential to regulate the soil nitrate pool and further reduce direct $\mathrm{N}_{2} \mathrm{O}$ emissions by both nitrification and denitrification (Dobbie and Smith, 2003a). The rate of $\mathrm{N}$ fertiliser application is also important as generally the higher the $\mathrm{N}$ fertiliser rate, the higher the $\mathrm{N}_{2} \mathrm{O}$ emissions (Hinton et al., 2015). Using the IPCC default $\mathrm{EF}_{1}$ assumes a linear relationship between $\mathrm{N}_{2} \mathrm{O}$ emissions and $\mathrm{N}$ fertiliser rate which Hinton et al (2015) observed. Other studies have observed nonlinear relationships between $\mathrm{N}_{2} \mathrm{O}$ emissions and $\mathrm{N}$ fertiliser rate (Hoben et al., 2011; McSwiney and Roberston, 2005).

In this study, $\mathrm{N}_{2} \mathrm{O}$ emissions were measured from spring barley after fertiliser applications of CAN and urea with and without $\mathrm{N}$ stabilisers. Nitrogen stabilisers are fertiliser additives that reduce environmental $\mathrm{N}$ losses thereby stabilising the $\mathrm{N}$ in the soil. These can either a) reduce urea $\mathrm{N}$ loss via volatilisation and are termed urease inhibitors or reduce $\mathrm{N}$ loss via denitrification of nitrate and are termed nitrification inhibitors. These stabilisers can thus increase fertiliser use efficiencies by increasing plant $\mathrm{N}$ uptake and crop yields. The $\mathrm{N}$ stabilisers evaluated in this study were the urease inhibitor $\mathrm{N}$-(n-butyl) thiophosphoric triamide (NBPT (trade name Agrotain ${ }^{\mathrm{TM}}$ ) and also referred to as n-BTPT in other studies), the nitrification inhibitor dicyandiamide (DCD), and the Maleic-Itaconic acid Co-polymer (MICO (trade name NutriSphere-N囚)) which is a urease and nitrification inhibitor. The aims of this study were to quantify the effect of $\mathrm{N}$ fertiliser rate and formulation on direct $\mathrm{N}_{2} \mathrm{O}$ emissions from spring barley in a temperate maritime climate and to develop crop specific emission factors for use in national $\mathrm{N}_{2} \mathrm{O}$ emissions inventories. The hypothesis of this study is that changing $\mathrm{N}$ fertiliser source from $\mathrm{CAN}$ to stabilised urea reduces $\mathrm{N}_{2} \mathrm{O}$ emissions. 


\section{$\underline{2.1 \text { Site description }}$}

109 Field plot trials were conducted on spring malting barley on a free-draining loam soil located

110 in Marshalstown, Co. Wexford (Table 1). This field site was located within the main malting

111 barley growing region in Ireland (Duffy et al., 2015) and was representative of the typical soil

112 type used for arable cropping. The site history was long term arable production for at least 20

113 years.

114

\section{$115 \quad 2.2$ Crop husbandry}

116 The spring barley (Hordeum vulgare L.) cultivar used was 'Sebastian'. The site was ploughed 117 to approximately $20 \mathrm{~cm}$ depth in February 2013 and March 2014. The crop was sown in mid-

118 April in both years and was harvested in mid-August in both years. The experiment ran from

119 April 2013 to April 2015 and generated emission factors for two years (crop sowing time to

120 the following sowing time each year). The site characteristics are described in Table 1 and are

121 based on the top $10 \mathrm{~cm}$ of soil which is the standard agronomic soil sampling depth in

122 Ireland. Each year basal P, K and S were applied to the soil, according to the Teagasc Green

123 Book of nutrient advice (Coulter and Lalor, 2008) to prevent nutrient deficiencies from occurring. A robust pesticide programme was applied to the crop to control weeds, pests and diseases as per standard agronomic practice for spring barley crops (Teagasc, 2015).

126

127

128

129

130

131 
132 Table 1. Site location and soil characteristics $(0-10 \mathrm{~cm}$ depth)

\begin{tabular}{ll}
\hline GPS Co-ordinates & $52^{\circ} 33^{\prime} 37.3^{\prime \prime} \mathrm{N} 6^{\circ} 36^{\prime} 09.0^{\prime \prime} \mathrm{W}$ \\
Drainage Class & Free- draining \\
Texture & Loam \\
Sand \% & 31.8 \\
Silt \% & 41.4 \\
Clay \% & 26.8 \\
Stone volume (v/v) & 28 \\
pH & 6.76 \\
LOI \% & 8.99 \\
Total C \% & 2.88 \\
Total N \% & 0.281 \\
C : N ratio & 10 \\
CEC (meq/100g) & 21.1 \\
Ca (mg/kg soil) & 1616 \\
K (mg/kg soil) & 267 \\
Mg (mg/kg soil) & 164 \\
P (mg/kg soil) & 37.3 \\
S (mg/kg soil) & \\
\hline
\end{tabular}

$135 \quad 2.3$ Experimental Design

136 A randomised block design was used with five replicates of each fertiliser formulation. In

137 addition to the unfertilised control, six fertiliser formulations were used: (i) CAN, (ii) urea

138 (iii) urea + NBPT (iv) urea + DCD (v) urea + NBPT + DCD, and (vi) urea + MICO included 139 in 2014 only. All fertiliser formulations were applied at the common $\mathrm{N}$ rate of $150 \mathrm{~kg} \mathrm{~N}^{-1}$ 
140 as this was the recommended $\mathrm{N}$ rate for spring barley as per the target crop yield. CAN and

141 urea were applied at additional rates and details of the $\mathrm{N}$ fertiliser rates used are shown in

142 Table 2. Each experimental unit (trial plot) measured $6 \mathrm{~m}$ by $2.5 \mathrm{~m}$. Fertiliser was applied in

143 two splits for all treatments. The first split comprised $30 \mathrm{~kg} \mathrm{~N} \mathrm{ha}^{-1}$ and was surface applied

144 within seven days of sowing. The second split was comprised of the remaining $\mathrm{N}$ fertiliser to

145 make up the individual treatment rate (for $150 \mathrm{~kg} \mathrm{~N} \mathrm{ha}^{-1}$ the $2^{\text {nd }}$ split was $120 \mathrm{~kg} \mathrm{~N} \mathrm{~h}^{-1}$ ) and

146 was applied during early to mid-tillering (Zadoks GS 20-25). The first split fertiliser was

147 applied $15^{\text {th }}$ April 2013 and the $23^{\text {rd }}$ April 2014. The second split was applied $13^{\text {th }}$ May in

148 both years. Pre-weighed fertiliser was applied by hand to the chamber base separately to the

149 plot area to ensure the correct $\mathrm{N}$ application rate within the chambers.

150

151 Table 2. Nitrogen fertiliser formulations and rate

\begin{tabular}{lccccc}
\hline & \multicolumn{5}{c}{ N Rate $\left(\mathbf{k g ~ N ~ h a} \mathbf{~ h}^{-1}\right)$} \\
Fertiliser Formulation & $\mathbf{1 0 0}$ & $\mathbf{1 2 5}$ & $\mathbf{1 5 0}$ & $\mathbf{1 7 5}$ & $\mathbf{2 0 0}$ \\
CAN & $\checkmark$ & $\checkmark$ & $\checkmark$ & $\checkmark$ & $\checkmark$ \\
Urea & $\checkmark$ & $\checkmark$ & $\checkmark$ & $\checkmark$ \\
Urea + NBPT & & & $\checkmark$ & \\
Urea + DCD & & $\checkmark$ & \\
Urea + NBPT + DCD & & $\checkmark$ & \\
Urea + MICO & & $\checkmark$
\end{tabular}

152

$154 \quad 2.4$ Soil and Climatic Analysis

155 Total daily rainfall, air temperature and humidity were recorded at a weather station adjacent

156 to the site. Atmospheric pressure from the nearest available weather station at Johnstown

157 Castle was used. Soil moisture was recorded on each day of $\mathrm{N}_{2} \mathrm{O}$ measurement to a depth of 
$15810 \mathrm{~cm}$ using a Delta T ML2 probe (Delta-T Devices, Burwell, Cambridge, UK). In addition

159 to this, soil samples were taken on a weekly basis at the beginning of the year and on each

160 day of measurement once the frequency of $\mathrm{N}_{2} \mathrm{O}$ measurement was reduced later in the

161 growing season. The gravimetric water content (GWC) of the soil was measured using these

162 soil samples. Soil samples were taken to $10 \mathrm{~cm}$ depth using a soil corer ( $2 \mathrm{~cm}$ diameter). Five

163 cores were taken from each plot, bulked together in sealed plastic bags and placed in a cool-

164 box. Following sampling (i.e. within 2 hours) the soil samples were taken to the laboratory

165 where they were wet sieved to $2 \mathrm{~mm}$ followed immediately by mineral $\mathrm{N}$ extraction using $2 \mathrm{M}$

166 potassium chloride $(\mathrm{KCl})$ (1:5 ratio of soil to $\mathrm{KCl}$ ) (Keeney and Nelson, 1982; Mulvaney,

167 1996). The mineral $\mathrm{N}$ extracts were analysed colorimetrically using an Aquakem 600A

168 (Aquakem 600A, 01621, Vantaa, Finland) to determine the concentration of the mineral N 169 species i.e. Total Oxidised $\mathrm{N}$ (TON (including nitrite $\left(\mathrm{NO}_{2}^{-}\right)$and nitrate $\left(\mathrm{NO}_{3}^{-}\right)$) and

170 ammonium-N $\left(\mathrm{NH}_{4}{ }^{+}-\mathrm{N}\right)$. Soil sampling and mineral $\mathrm{N}$ extraction occurred weekly at the

171 beginning of the experiment and was reduced to once fortnightly coinciding with the

172 frequency of $\mathrm{N}_{2} \mathrm{O}$ measurements. The gravimetric water content (GWC) of the soil samples

173 was also measured on each day of sampling .Soil bulk density was measured four times over

174 the course of the experiment (after the crop was planted and after harvest) and this was used

175 with GWC to calculate volumetric water content (VWC). Soil bulk density and VWC were

176 used to calculate water filled pore space percentage (WFPS \%)

177

$178 \quad 2.5$ Nitrous oxide $\left(\mathrm{N}_{2} \underline{O}\right.$ ) sampling and analysis

179 Daily $\mathrm{N}_{2} \mathrm{O}$ fluxes were measured using the static chamber technique (Smith et al., 1995;

180 Chadwick et al., 2014), adhering to the methodology guidelines compiled by the Global

181 Research Alliance (de Klein and Harvey, 2012). The $\mathrm{N}_{2} \mathrm{O}$ chamber measurement area was

$1820.4 \mathrm{~m}^{2}$. Collars were installed to at least $5 \mathrm{~cm}$ into the soil (Smith et al., 2012) and contained a 
neoprene filled channel in order to maintain an air-tight seal. Collars were installed at least three days prior to the first sampling and were left in place for the duration of the study. Collars were removed for harvest and ploughing events and then reinstalled afterwards. When sampling, a stainless steel lid was placed onto the collar and a $10 \mathrm{~kg}$ weight was placed on top to compress the neoprene gasket, thus ensuring an airtight seal inside the chamber.

188 There were two different chamber sizes. A chamber with air volume $0.017 \mathrm{~m}^{3}$ (10cm height) was used from sowing until Zadoks GS 32-33 (stem extension). Subsequently, larger chambers with an air volume of $0.096 \mathrm{~m}^{3}(60 \mathrm{~cm}$ height) were used until harvest, after which small chambers were used again. Chambers were sampled prior to fertilisation, and then on a reducing temporal resolution for four weeks after fertiliser was applied i.e. four times per week for the first two weeks, twice per week for the next two weeks, and once per week thereafter. This sampling frequency was adopted to capture the period of most active $\mathrm{N}$ loss in more detail. In Year two, $\mathrm{N}_{2} \mathrm{O}$ sampling was reduced to once every three weeks (after the initial four weeks of sampling after fertilisation) after reviewing year one data. The chamber

197 lids were left on for 40 minutes, (larger chamber lids were left on for 60 minutes), then a 10

$198 \mathrm{ml}$ sample was taken from each chamber and immediately injected into a $7 \mathrm{ml}$ pre-evacuated exetainer (Sigma-Aldrich, UK) fitted with double wadded septa (Labco, High Wycombe, UK). On each sampling date eight samples of ambient air were taken around the site and the average used as time zero (T0) sample for each chamber. Chadwick et al. (2014) have shown that ambient samples are a useful surrogate for individual chamber T0 samples. On each sampling day, five chambers were chosen at random to check for linearity. These chambers were sampled at T0, T15, T30, T40, T60 and samples were statistically analysed to test for flux/no flux, quadratic or linearity. On each sampling day two sampling vials were injected with $0.5 \mathrm{ppm} \mathrm{N}_{2} \mathrm{O}$ standard from the laboratory to ensure the integrity of samples during storage. Samples were analysed for $\mathrm{N}_{2} \mathrm{O}$ using an electron capture detector (ECD) at $300^{\circ} \mathrm{C}$. 
208 A CTC Analytics Combi-pal auto sampler (CTC Analytics, Industriestrasse 20, Zwingen,

209 Switzerland) was used to inject gas samples into the Bruker Gas Chromatograph (Bruker,

210 Bremen, Germany). Evolved $\mathrm{N}_{2} \mathrm{O}$ was expressed as parts per million by volume (ppmv)

211 having allowed for ambient concentrations and up-scaled to a flux in $\mathrm{g} \mathrm{N}_{2} \mathrm{O}-\mathrm{N} \mathrm{ha}^{-1} \mathrm{~d}^{-1}$ using

212 the following equation adapted from de Klein and Harvey (2012):

213

214

$$
\left.\mathrm{F}_{\mathrm{N} 2 \mathrm{O}}=(\partial c / \partial t) *((M * P) / R * T)\right) *(V / A)
$$

215 Where:

$216 \partial c$ is the change in gas concentration in the chamber headspace during the enclosure period

217 (ppbv), $\partial t$ is the enclosure period expressed in minutes, $\mathrm{M}$ is the molar mass of $\mathrm{N}_{2} \mathrm{O}-\mathrm{N}(28 \mathrm{~g}$ $\left.\mathrm{mol}^{-1}\right), \mathrm{P}$ is atmospheric pressure $(\mathrm{Pa})$ at the time of sampling, $\mathrm{T}$ is the temperature $(\mathrm{K})$ at the

219 time of sampling, $\mathrm{R}$ is the ideal gas constant $\left(8.314 \mathrm{~J} \mathrm{k}^{-1} \mathrm{~mol}^{-1}\right), \mathrm{V}$ is the headspace volume of 220 the chamber and $\mathrm{A}$ is the area covered by the chamber (ha).

221 Sampling occurred between 10 am and 2 pm each day as per Chadwick et al. (2014). The

222 limit of detection of the method was calculated by averaging the standard deviation of all 223 ambient samples for each year and then subtracting three standard deviations. This was 0.26 ppm and 0.28 ppm for 2013 and 2014, respectively. Anything below this was excluded from the study. In total over the two years 39 data points were removed as limits of detection out of a total of 5980 data points.

\subsection{Emission Factor calculation}

229 Cumulative $\mathrm{N}_{2} \mathrm{O}$ fluxes from each chamber were calculated using trapezoidal integration to 230 interpolate fluxes between sampling dates. Trapezoidal integration was used to linearly 231 integrate fluxes from one sampling day to the next sampling day in order to generate fluxes 232 for 365 days in order to generate cumulative fluxes. For each formulation, cumulative fluxes 
were calculated using the mean of the five replicates. The EFs were then calculated using the

234 following equation:

235

$E F(\%)=\underline{N_{2}} \underline{O-N}$ cumulative (formulation) $-\mathrm{N}_{2} \underline{O}-\mathrm{N}$ cumulative (unfertilised control) $\times 100$

Annual EFs were calculated over a 365 day period (IPCC, 2006). As calendar year (January

- December) measurement is not appropriate for tillage systems, EFs were calculated from sowing date to the subsequent years sowing date and normalised to 365 days. Nitrous oxide yield efficiency was calculated by dividing the cumulative $\mathrm{N}_{2} \mathrm{O}-\mathrm{N} \mathrm{ha}^{-1}(\mathrm{~kg})$ of a treatment by the grain yield $\left(\mathrm{t} \mathrm{ha}^{-1}\right)$ for the same treatment which produced $\mathrm{N}_{2} \mathrm{O}$ yield efficiency $\left(\mathrm{kg} \mathrm{N}_{2} \mathrm{O}\right.$ -

$244 \mathrm{~N} \mathrm{t}^{-1}$ grain).

\subsection{Linearity of $\mathrm{N}_{2}$ O flux}

247 Results from the randomly selected $\mathrm{N}_{2} \mathrm{O}$ chambers, used to assess if the $\mathrm{N}_{2} \mathrm{O}$ flux was linear, 248 showed on average linear accumulation. Initial analysis of this data was conducted to assess 249 if a flux in $\mathrm{N}_{2} \mathrm{O}$ emissions occurred. In some cases there was no flux evident (Table 3). The chambers showing $\mathrm{N}_{2} \mathrm{O}$ flux were then analysed for linear or quadratic accumulation of $\mathrm{N}_{2} \mathrm{O}$.

251 Over $90 \%$ of these chamber measurements in both sites in both years showed linear 252 accumulation according to the criteria of Chadwick et al. (2014) (Table 3). This shows that 253 the assumption of linear accumulation in the headspace can be used. This is in agreement with work conducted by Chadwick et al. (2014) where over $90 \%$ of chamber measurements $(\mathrm{n}=1970)$ from multiple field experiments, showed linear $\mathrm{N}_{2} \mathrm{O}$ accumulation. 
Table 3. Linearity samples for 2013 and 2014

\begin{tabular}{lll} 
& $\mathbf{2 0 1 3}$ & $\mathbf{2 0 1 4}$ \\
\hline Total No. chambers & 260 & 212 \\
Chambers without $\mathrm{N}_{2} \mathrm{O}$ flux & 212 & 73 \\
Chambers with $\mathrm{N}_{2} \mathrm{O}$ flux & 48 & 139 \\
\hline Of chambers with flux & $\mathbf{\%}$ & \\
\hline Quadratic & $\mathbf{8}$ & $\mathbf{6}$ \\
Linear & $\mathbf{9 2}$ & $\mathbf{9 4}$ \\
\hline
\end{tabular}

259

260

\subsection{Statistical Analysis}

262 Statistical analysis was conducted using the PROC GLIMMIX and PROC MIXED

263 procedures in SAS 9.3 (2002-2010, SAS Institute Inc., Cary, NC, U.S.A.). PROC MIXED

264 was used to conduct a repeated measures analysis of variance (ANOVA) of the temporal $\mathrm{N}_{2} \mathrm{O}$

265 and mineral $\mathrm{N}$ data. Residual graphs were generated to check for normality. Log

266 transformation of all temporal data was conducted as there was high variability within the

267 dataset and nonconformity with the assumptions about normality in ANOVA. Residual

268 influence statistics were used to identify potential outliers and showed which data points were

269 the most influential on the entire dataset. These 'potential outliers' were then assessed to

270 check if they were genuine outliers. The assessment of the temporal $\mathrm{N}_{2} \mathrm{O}$ data identified only

271 six individual flux measurements that were 'genuine outliers'. These were subsequently

272 removed from the dataset and the average of the other four replicates was then used for that

273 day for gap-filling to generate the cumulative flux. The PROC GLIMMIX procedure was

274 used to test for treatment differences in cumulative emissions. Significant differences were

275 determined according to the F-protected least significant difference test $(\mathrm{p}<0.05)$. 
276 Dixons test was used to identify outliers in the ambient data. The minimum detectable flux

277 was then calculated according to Appendix 2 in the chamber methodology guidelines (de

278 Klein and Harvey, 2012). Repeatability, standard deviation and repeatability limit was

279 calculated as per (Ellison et al., 2009). The minimum detectable flux (MDF) was calculated

280 to be 2.59 and $7.78 \mathrm{~g} \mathrm{~N}_{2} \mathrm{O}-\mathrm{N} \mathrm{ha}^{-1}$ day $^{-1}$ in 2013 for small and large chambers, respectively. In

2812014 the MDF was calculated to be 2.86 and $7.84 \mathrm{~g} \mathrm{~N}_{2} \mathrm{O}-\mathrm{N} \mathrm{ha}^{-1}$ day $^{-1}$ for small and large

282 chambers, respectively.

283

2843 Results

$285 \quad 3.1$ Soil and Climatic conditions

286 The weather during the experiment was typical of the weather for this region with most of the

287 rainfall occurring during the autumn and winter months and the highest temperatures

288 occurring during the summer months (Figure 1a and 2a). In both years, the highest average

289 daily temperature was $17^{\circ} \mathrm{C}$ in July and the highest total monthly rainfall was in October with

$290189 \mathrm{~mm}$ in 2013 and $173 \mathrm{~mm}$ in 2014 . Total monthly rainfall and average temperature were

291 higher in April (68.4mm) and May (74.8mm) in 2014 compared with April and May 2013

292 with $47.2 \mathrm{~mm}$ and $53.6 \mathrm{~mm}$ and the 30 year average with 59.1 and $55.7 \mathrm{~mm}$ for April and May

293 respectively. Water filled pore space ranged from $15.74 \%-66.09 \%$ in 2013 and $28.6 \%$ -

$29468.2 \%$ in 2014 with the lowest WFPS\% occurring in the summer months. Soil total oxidised

295 nitrogen (TON) and ammonium $\left(\mathrm{NH}_{4}{ }^{+}\right)$concentrations increased after fertiliser application

296 (Figure $1 \mathrm{~b}$ and $2 \mathrm{~b}$ ). Elevated soil TON levels occurred following the $2^{\text {nd }}$ split application of

297 CAN. In 2013, levels reached $95.2 \mathrm{mg}^{\mathrm{TON} \mathrm{kg}}{ }^{-1}$ soil two days post-application and $106.8 \mathrm{mg}$

298 TON kg${ }^{-1}$ soil 24 days after application for CAN. After this TON levels from CAN were

299 reduced to below $50 \mathrm{mg}$ TON kg${ }^{-1}$ soil. In 2014, TON levels from CAN reached $190 \mathrm{mg}$

$300 \mathrm{TON} \mathrm{kg}{ }^{-1}$ soil three days after application. Generally, all other fertiliser formulations had 
lower TON levels than CAN. Urea + DCD and urea + NBPT + DCD levels were similar to

302 the unfertilised control levels. The highest $\mathrm{NH}_{4}{ }^{+}$concentration in 2013 was $161.13 \mathrm{mg} \mathrm{NH}_{4}{ }^{+}$ $\mathrm{kg}^{-1}$ soil (urea + NBPT + DCD) and in 2014 was $257.98 \mathrm{mg} \mathrm{NH}_{4}{ }^{+} \mathrm{kg}^{-1}$ soil (urea + DCD). All

304 fertiliser formulations produced an $\mathrm{NH}_{4}{ }^{+}$peak after application but CAN produced the 305 highest TON peak.

\section{$\underline{3.2 \mathrm{~N}_{2}}$ O emissions: fertiliser formulation and $\mathrm{N}$ stabilisers at $150 \mathrm{~kg} \mathrm{~N} \mathrm{ha}^{-1}$}

308 Nitrous oxide emissions increased from background levels post-fertiliser application with the highest observed fluxes of $44 \mathrm{~g} \mathrm{~N}_{2} \mathrm{O}-\mathrm{N} \mathrm{ha}^{-1} \mathrm{~d}^{-1}$ in 2013 (Figure 1c) and $43 \mathrm{~g} \mathrm{~N}_{2} \mathrm{O}-\mathrm{N} \mathrm{ha}^{-1} \mathrm{~d}^{-1}$ in 2014 (Figure 2c). This peak in $\mathrm{N}_{2} \mathrm{O}$ emission corresponded closely with timing of fertiliser application and rainfall occurring 15 and 13 days following the main fertiliser split application in 2013 and 2014 respectively. The association of $\mathrm{N}_{2} \mathrm{O}$ emissions with fertiliser application was most pronounced following the second fertiliser application of $120 \mathrm{~kg} \mathrm{~N} \mathrm{ha}{ }^{-1}$.

314 The initial split was $30 \mathrm{~kg} \mathrm{~N} \mathrm{ha}^{-1}$ and resulted in a lower quantity of $\mathrm{N}_{2} \mathrm{O}$ loss.

315 In 2013 the largest daily fluxes came from urea, CAN and urea + NBPT, in that order. The

316 profile of temporal emissions from urea + DCD and urea + NBPT + DCD were similar to the unfertilised control. Approximately 16 weeks after fertiliser application, emissions returned to background levels (i.e. similar to that of the unfertilised control) and remained so for the remainder of the year in 2013 for all formulations.

In 2014 there was a peak in emissions after fertiliser application with the largest daily fluxes from CAN, urea + NBPT and urea in that order. Approximately four to six weeks after the second split fertiliser application emissions returned to background levels and remained so for the remainder of the year for all formulations. 
327 Cumulative $\mathrm{N}_{2} \mathrm{O}$ emissions were all below $0.5 \%$ across all formulations and years. In both 328 years CAN produced significantly higher emissions than the unfertilised control with $1161 \mathrm{~g}$ $329 \mathrm{~N}_{2} \mathrm{O}-\mathrm{N} \mathrm{ha}^{-1}$ in 2013 and $513 \mathrm{~g} \mathrm{~N}_{2} \mathrm{O}-\mathrm{N} \mathrm{ha}^{-1}$ in 2014 (Table 4) compared with $424 \mathrm{~g} \mathrm{~N}_{2} \mathrm{O}-\mathrm{N}^{-}$

$330{ }^{1}$ from the control in 2013 and $191 \mathrm{~g} \mathrm{~N}_{2} \mathrm{O}-\mathrm{N} \mathrm{ha}^{-1}$ from the control in 2014. In $2013 \mathrm{~N}_{2} \mathrm{O}$ loss

331 from CAN, urea, urea + DCD was not significantly different. Urea + NBPT and urea + NBPT

332 + DCD had significantly lower emissions compared to CAN and were also not significantly

333 different to $\mathrm{N}_{2} \mathrm{O}$ emissions from the unfertilised control. In 2014 urea + DCD was the sole

334 fertiliser formulation which had significantly lower $\mathrm{N}_{2} \mathrm{O}$ loss compared to CAN, urea and

335 urea + MICO. EFs ranged from $0-0.49 \%$ with the numerically highest EF of $0.49 \%$ from

336 CAN in 2013. CAN and urea had the highest direct EFs in each year and all EFs were lower

337 than the IPCC default of $1 \%$ regardless of formulation. Urea + NBPT + DCD had the lowest

338 EF in 2013 and urea + DCD had the lowest EF in 2014 and the lowest mean EF. 
351 Table 4. Cumulative direct $\mathrm{N}_{2} \mathrm{O}$ emissions in $\mathrm{g} \mathrm{N}_{2} \mathrm{O}-\mathrm{N} \mathrm{ha}^{-1}$ and emission factors for 2013 and $352 \quad 2014$

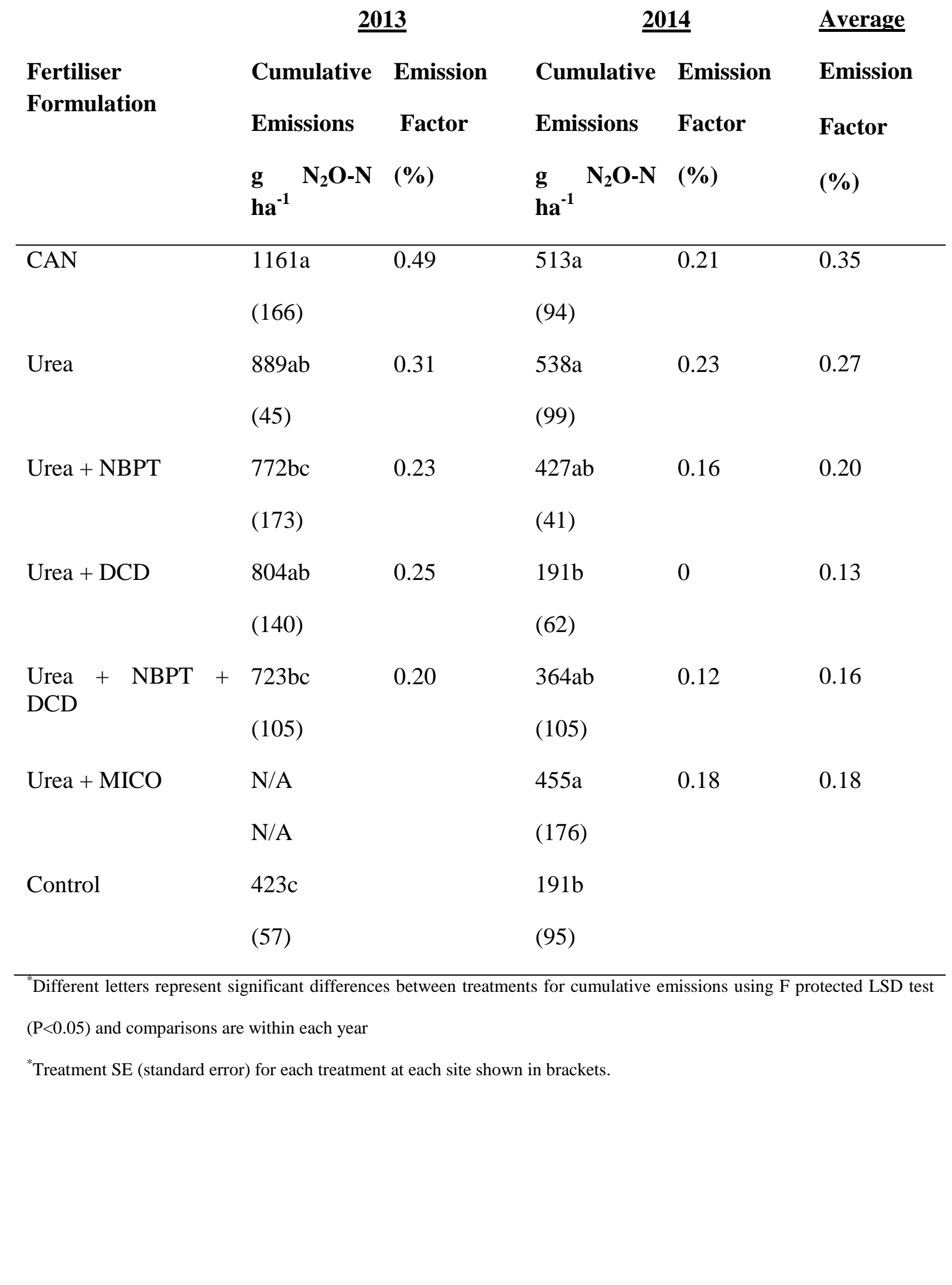


362 The impact of $\mathrm{N}$ rate $\left(100-200 \mathrm{~kg} \mathrm{~N} \mathrm{ha}^{-1}\right)$ on $\mathrm{EF}_{1}$ was unclear. There was no significant

363 impact of application rate on the CAN EF in either year as evidenced by the lack of a

364 significant correlation between the EF and $\mathrm{N}$ rate (Table 5). However, a significant negative 365 correlation between $\mathrm{N}$ rate and the urea EF was observed in 2013 but not in 2014 (Table 5).

366 The model that best fitted this equation was quadratic with an $r^{2}$ value of 0.96 ; the equation of 367 the line is presented in Table 5.

368

Table 5. Effect of $\mathrm{N}$ rate on $\mathrm{N}_{2} \mathrm{O}$ emission factors for $\mathrm{CAN}$ and Urea

Treatment Pvalue Equation*

(slope different to zero)

\begin{tabular}{lll}
\hline CAN 2013 & 0.258 & N/A
\end{tabular}

Urea $2013 \quad 0.0321 \quad \mathrm{y}=8 \mathrm{E}-05 \mathrm{x}^{2}-0.0287 \mathrm{x}+2.8594$

$\begin{array}{lll}\text { CAN } 2014 \quad 0.225 & \text { N/A }\end{array}$

Urea $2014 \quad 0.0811 \quad$ N/A

$* \mathrm{y}=$ Emission factor and $\mathrm{x}=\mathrm{N}$ fertiliser rate

$\underline{3.5 \mathrm{~N}_{2}} \underline{\mathrm{O} \text { yield efficiency }}$

373 Nitrous oxide yield efficiency ranged from $0.09-0.16 \mathrm{~kg} \mathrm{~N}_{2} \mathrm{O}-\mathrm{N} \mathrm{t}^{-1}$ grain in 2013 and $0.02-$

$3740.07 \mathrm{~kg} \mathrm{~N}_{2} \mathrm{O}-\mathrm{N} \mathrm{t}^{-1}$ grain in 2014. There were no significant differences between fertiliser

375 formulations in either year but there were differences between the unfertilised control and

376 fertiliser treatments (Figure 3). In 2013, the unfertilised control was significantly higher than

377 all fertiliser treatments with $0.16 \mathrm{~kg} \mathrm{~N}_{2} \mathrm{O}-\mathrm{N} \mathrm{t}^{-1}$ grain except for $\mathrm{CAN}$ and in 2014 the

378 unfertilised control was higher than urea + DCD with $0.05 \mathrm{~kg} \mathrm{~N}_{2} \mathrm{O}-\mathrm{N} \mathrm{t}^{-1}$ grain and not different to any other treatment. 


\subsection{Effect of environmental factors on $\mathrm{N}_{2}$ O emissions}

382 The application of $\mathrm{N}$ resulted in a peak in soil mineral $\mathrm{N}$ concentrations with $\mathrm{CAN}$ producing 383 significantly higher $\mathrm{NO}_{3}{ }^{-}$peaks compared to other $\mathrm{N}$ forms and all fertiliser formulations 384 producing $\mathrm{NH}_{4}{ }^{+}$peaks. This study showed that using a urea based fertiliser reduced the soil $385 \mathrm{NO}_{3}{ }^{-}$pool compared to CAN. Thus, there is less TON for denitrification and leaching from the urea based fertilisers. The soil $\mathrm{NH}_{4}{ }^{+}$pool was similar regardless of the $\mathrm{N}$ formulation used.

Whilst rainfall and temperature at the time of fertiliser application were higher in 2014 than in 2013, cumulative emissions were lower in 2014 compared with 2013. In 2013 there were multiple emission peaks resulting in higher cumulative emissions whereas in 2014 there was one main peak after each fertiliser application. The slightly lower levels of $\mathrm{N}_{2} \mathrm{O}$ in 2014 could indicate that either complete denitrification occurred producing $\mathrm{N}_{2}$ instead of $\mathrm{N}_{2} \mathrm{O}$ (Focht et al., 1979), $\mathrm{NO}_{3}{ }^{-}$or that the nitrate was leached due to higher rainfall events combined with the free-draining soil texture, or that more $\mathrm{N}$ was taken up by the crop due to less drought stress.

In general, cumulative emissions were low ranging from $191 \mathrm{~g} \mathrm{~N}_{2} \mathrm{O}-\mathrm{N} \mathrm{ha}^{-1} \mathrm{yr}^{-1}$ to $1161 \mathrm{~g}$ $\mathrm{N}_{2} \mathrm{O}-\mathrm{N} \mathrm{ha}^{-1} \mathrm{yr}^{-1}$ and with $\mathrm{EF}_{1}$ ranging from 0 to $0.49 \%$. This is consistent with previous studies on spring barley sites in Ireland, where EF for CAN during the growing season (not full year) was observed to be $0.5 \%$ (Abdalla et al., 2010). The relatively low $\mathrm{EF}_{1}$ could be explained, in part, by the soil characteristics. The soil was a free-draining cambisol with a $\mathrm{C}$ content of $2.88 \%$, which is typical of Irish arable soils. In a meta-analysis of over 1000 studies, Stehfest and Bouwman (2006) concluded that $\mathrm{N}_{2} \mathrm{O}$ emissions were significantly 403 lower on soils with SOC $<3 \%$ and Gilsanz et al (2016) observed the lowest EFs in soil 404 textures with low clay content (less than 50\%) and with sand content greater than 50\%. In a 
study at three arable sites, the $\mathrm{EF}_{1}$ for ammonium nitrate was observed to be substantially lower than the default value $(0.2 \%$ and $0.33 \%)$ at two free-draining sites (Bell et al., 2015). In contrast, grasslands exhibit both higher mean emissions and a larger range in EFs (Harty et al., 2016). Dobbie and Smith (2003a) reported $\mathrm{EF}_{1}$ ranging from 1\%-3\% in Scottish grasslands whilst previous studies on total $\mathrm{N}_{2} \mathrm{O}$ losses in Irish grasslands (including $\mathrm{N}$ 410 deposition form fertiliser $\left(\mathrm{EF}_{1}\right)$ and animal excreta $\left(\mathrm{EF}_{3}\right)$ ) have exhibited a range from $0.7 \%$ to 7.7\% (Hyde et al., 2006; Rafique et al., 2011; Li et al., 2011, Burchill et al., 2014).

\subsection{Effect of fertiliser formulation and incorporation of $\mathrm{N}$ stabilisers on $\mathrm{N}_{2}$ O emissions}

$414 \mathrm{~N}_{2} \mathrm{O}$ emission peaks in general corresponded with rainfall events and elevated soil TON and

$415 \mathrm{NH}_{4}{ }^{+}$concentrations. The majority of $\mathrm{N}_{2} \mathrm{O}$ emissions occurred after the second and the larger 416 split fertiliser application with the highest $\mathrm{N}_{2} \mathrm{O}$ emissions and EFs associated with CAN and 417 urea application. There were no significant differences in $\mathrm{N}_{2} \mathrm{O}$ emissions between CAN and urea. A comparison between urea and ammonium nitrate (AN) at three UK sites also found no differences in $\mathrm{N}_{2} \mathrm{O}$ emissions between fertiliser formulations, with higher emissions for both fertilisers at the site with highest rainfall (Bell et al., 2015). Similarly, Louro et al. (2015) reported no significant fertiliser formulation effect on $\mathrm{N}_{2} \mathrm{O}$ emissions. In contrast,

Dobbie and Smith (2003a) observed lower $\mathrm{N}_{2} \mathrm{O}$ emissions associated with urea application compared to ammonium nitrate (AN). This effect was season dependant with no differences when fertiliser was applied in late summer. The findings from this study suggest that the addition of the nitrification inhibitor DCD to urea has potential to reduce $\mathrm{N}_{2} \mathrm{O}$ emissions by $30 \%$ compared to CAN. The inhibitory effect of DCD can vary depending on climate and soil conditions as well as vegetation type (Gilsanz et al., 2016) and is likely to be more effective where there are higher losses such as wetter soils. Bell et al. (2015) observed a decrease in the $\mathrm{EF}_{1}$ for $\mathrm{AN}$ from $0.55 \%$ to $0.06 \%$ upon application of DCD. In addition, Dobbie and 
430 Smith (2003a) observed a 50\% reduction in cumulative emissions using urea + DCD 431 compared to urea alone, but observed no benefit of urea + NBPT on direct $\mathrm{N}_{2} \mathrm{O}$ emissions.

432 The potential effects of DCD uptake by the plant and contamination in crop off takes is 433 needed as recently highlighted in New Zealand (Pal et al., 2016). In studies with higher 434 emissions the inclusion of a urease inhibitor with urea reduced $\mathrm{N}_{2} \mathrm{O}$ emissions compared with 435 CAN (McTaggart et al., 1997). While NBPT treated urea did not reduce direct $\mathrm{N}_{2} \mathrm{O}$ emissions compared to urea in this study, inclusion of NBPT with urea has been shown to reduce volatilisation from urea (Watson et al., 2009; Forrestal et al., 2015) which will reduce indirect $\mathrm{N}_{2} \mathrm{O}$ emission associated with the deposition of atmospheric $\mathrm{NH}_{3}$ (Asman et al., 1998). Urea + MICO showed no effect on $\mathrm{N}_{2} \mathrm{O}$ emissions compared to CAN or urea. This corresponds 440 with the literature which shows that urea + MICO is not an effective nitrification or urease 441 inhibitor (Chien et al., 2014;Franzen et al., 2011., Goos, 2013). The EFs for all fertiliser 442 formulations were $<50 \%$ of the IPCC default value of $1 \%$. Against this background these 443 fertiliser formulations appear to have similar $\mathrm{N}_{2} \mathrm{O}$ loss potential in spring barley which tends 444 to be cropped to free draining sites similar to this study. Other studies on arable land in 445 similar climates have also shown EFs lower than the IPCC default (Bell et al., 2015; Abdalla 446 et al., 2010).

447 The $\mathrm{N}_{2} \mathrm{O}$ yield efficiency was highest for the unfertilised control but there were no 448 differences between fertiliser formulations which is in agreement with Hinton et al (2015). 449 It's important to account for crop yield as well as $\mathrm{N}_{2} \mathrm{O}$ emissions when assessing fertiliser 450 formulations to determine if they are economically viable (Hinton et al., 2015). This study 451 showed similar $\mathrm{N}_{2} \mathrm{O}$ yield efficiency regardless of the fertiliser formulation used.

452 
456 There was no EF response to rate of $\mathrm{N}$ application for CAN and urea in 2014. Bell et al 457 (2015) also observed no consistent increase in $\mathrm{EF}_{1}$ in response to increased rate of $\mathrm{AN}$ applied to arable cropped soils. In the current study there was a negative correlation observed between $\mathrm{EF}_{1}$ and rate of urea application 2014, with $\mathrm{EF}_{1} 0.7 \%$ at the lowest $\mathrm{N}$ application (100 kg N ha $\left.{ }^{-1}\right)$ compared to $0.4 \%$ at the highest $\mathrm{N}$ application $\left(200 \mathrm{~kg} \mathrm{~N} \mathrm{ha}^{-1}\right)$. This may be related to higher ammonia volatilisation occurring at higher $\mathrm{N}$ fertiliser application rates (Black et al., 1985; Van der Weerden and Jarvis, 1997). The negative or lack of correlation between $\mathrm{EF}_{1}$ and applied $\mathrm{N}$ rate in the present study indicates that higher $\mathrm{NH}_{3}$ loss may have taken place and this could result in reduced yields which has been observed in previous studies (Conry et al., 1997; Gately, 1994; Devine and Holmes, 1963). The addition of NBPT protects against this $\mathrm{NH}_{3}$ loss with reductions of $78.5 \%$ on average measured in Irish grassland (Forrestal et al., 2015).

\subsection{Emission Factors and comparison to IPCC default}

470 Over the two year period of the study the EFs from all fertiliser formulations ranged from $0 \%$ 471 (from urea + DCD in 2014) - 0.49\% (from CAN in 2013). Other studies on UK soils have shown higher EFs from AN than those observed from CAN in this study (Hinton et al., 2015; Dobbie et al., 1999). The fact that the highest EF recorded $(0.49 \%)$ was half the magnitude of 474 the IPCC $1 \%$ default, highlights the potential importance of countries moving to a tier 2 475 methodology using system specific data to generate more accurate $\mathrm{N}_{2} \mathrm{O}$ emission inventories. 476 Further research is required in order to determine the appropriateness of the use of the default 477 EF in other scenarios such as different land use types. Furthermore the use of nitrification 478 inhibitors significantly decreased the observed EF. While the use of urease inhibitors did not 479 lead to significant reductions in direct $\mathrm{N}_{2} \mathrm{O}$ EFs, potential reductions in ammonia 
volatilisation as a result of urease inhibition could significantly reduce indirect $\mathrm{N}_{2} \mathrm{O}$ losses associated with the redeposition of atmospheric ammonia $\left(\mathrm{EF}_{4}\right)$.

482

483

\section{Conclusions}

484 Overall, $\mathrm{N}_{2} \mathrm{O}$ emissions from the fertilisers tested in this study were less than half the IPPC 485 default value of $1 \%$. The lack of a clear relationship between fertiliser rate and direct $\mathrm{N}_{2} \mathrm{O}$ emissions questions the appropriateness of the IPCC default values on soils with low emissions in temperate conditions. This site is representative of the soil type for the majority of spring barley in Ireland and so, based on this study, it is likely that $\mathrm{N}_{2} \mathrm{O}$ emissions from the majority of spring barley in Ireland are below the IPCC default value. In terms of fertiliser form, it is important to account for indirect emissions from $\mathrm{NH}_{3}$ volatilisation when calculating EFs upon switching from ammonium nitrate to urea-based fertiliser forms, as otherwise total emissions associated with $\mathrm{N}$ application will be underestimated. The present research emphasises the importance of developing country and system specific emission

494 factors to better estimate greenhouse gas emissions from agriculture.

495

\section{Acknowledgements}

497 We thank the Department of Agriculture, Food and the Marine (Grant No. 11/S/138), the Agricultural Greenhouse Gas Research Initiative for Ireland (Grant No. 10/RD/SC/716) and the Walsh Fellowship Scheme for funding this work. We thank the technical and farm staff at

500 Teagasc Johnstown Castle and Oak Park for their help with sampling and analysis and thanks to Jim Grant for help with statistical analysis. We thank the agricultural catchments program for weather data and farmer James Masterson for access to the field site. 
504 Figure 1. 2013 temporal emissions data (a) daily total rainfall (mm) and daily average temperature $\left({ }^{\circ} \mathrm{C}\right)$ and, (b) daily soil mineral $\mathrm{N}$ concentrations $(0-10 \mathrm{~cm})$. (c) daily $\mathrm{N}_{2} \mathrm{O}$

506 emissions in $\mathrm{g} \mathrm{N}_{2} \mathrm{O}-\mathrm{N} \mathrm{ha}^{-1}$ day $^{-1} *$ arrows represent fertiliser application

508 Figure 2. temporal emissions data (a) daily total rainfall $(\mathrm{mm})$ and daily average temperature

509 ( $\left.{ }^{\circ} \mathrm{C}\right)$ and, (b) daily soil mineral $\mathrm{N}$ concentrations $(0-10 \mathrm{~cm})$. (c) daily $\mathrm{N}_{2} \mathrm{O}$ emissions in $\mathrm{g}$

$510 \quad \mathrm{~N}_{2} \mathrm{O}-\mathrm{N} \mathrm{ha}^{-1}$ day $^{-1} *$ arrows represent fertiliser application

511

512 Figure 3. $\mathrm{N}_{2} \mathrm{O}$ yield efficiency $\left(\mathrm{kg} \mathrm{N}_{2} \mathrm{O}-\mathrm{N} \mathrm{t}^{-1}\right.$ grain) for 2013 and $2014 *$ Different letters

513 represent significant differences between treatments using F protected LSD test $(\mathrm{P}<0.05)$ and

514 comparisons are within each year

515

516

517

518

519

520

521

522

523

524

525

526

\section{References}

527 Abdalla, M., Jones, M., Ambus, P., Williams, M., 2010. Emissions of nitrous oxide from

528 Irish arable soils: effects of tillage and reduced N input. Nutr. Cycl. Agroecosyst. 86, 53-65. 
530 Asman, W.A.H., Sutton, M.A., Schjørring, J.K., 1998. Ammonia: emission, atmospheric 531 transport and deposition. New Phytol. 139,27-48.

533 Bell, M., Hinton, N., Cloy, J., Topp, C., Rees, R., Cardenas, L., Scott, T., Webster, C., 534 Ashton, R., Whitmore, A., 2015. Nitrous oxide emissions from fertilised UK arable soils: 535 Fluxes, emission factors and mitigation. Agric. Ecosys. Environ. 212, 134-147.

Black, A.S., Sherlock, R.R., Smith, N.P., Cameron, K.C., Goh, K.M., 1985. Effects of form 538 of nitrogen, season, and urea application rate on ammonia volatilisation from pastures. N. Z. 539 J. Agric. Res. 28,469-474.

Bremner, J.M., Blackmer, A.M., 1978. Nitrous oxide: emission from soils during nitrification of fertilizer nitrogen. Science. 199,295-296.

544 Burchill, W., Li, D., Lanigan, G.J., Williams, M., Humphreys, J., 2014. Interannual variation 545 in nitrous oxide emissions from perennial ryegrass/white clover grassland used for dairy 546 production. Glob. Change Biol. 20,3137-3146.

548 Chadwick, D.R., Cardenas, L., Misselbrook, T.H., Smith, K.A., Rees, R.M., Watson, C.J., 549 McGeough, K.L., Williams, J.R., Cloy, J.M., Thorman, R.E., Dhanoa, M.S., 2014. 550 Optimizing chamber methods for measuring nitrous oxide emissions from plot-based 551 agricultural experiments. Eur. J. Soil Sci. 65, 295-307. 
553 Chien, S.H., Edmeades, D., McBride, R., Sahrawat, K.L., 2014. Review of Maleic-Itaconic

554 Acid Copolymer Purported as Urease Inhibitor and Phosphorus Enhancer in Soils. Agronomy

555 J.106,423-430.

556

557 Conry, M.J., 1997. The Influence of Different Nitrogenous Fertilisers and Foliar-Applied

558 Sulphur on the Yield, Grain Nitrogen and Screenings of Spring Malting Barley. In Biol.

559 Environ.: Proceedings of the Royal Irish Academy, 133-138.

560 Coulter, B.S., Lalor, S. 2008. Major and micro nutrient advice for productive agricultural

561 crops. Teagasc, Johnstown Castle, Co. Wexford, Ireland.

562

563 Davidson, E. A., 2009. The contribution of manure and fertilizer nitrogen to atmospheric

564 nitrous oxide since 1860. Nature Geosci. 2, 659-662.

566 De Klein, C.A.M., Harvey, M. (Eds.), 2012. Nitrous oxide chamber methodology guidelines.

567 Version 1.0. Global Research Alliance, New Zealand.

568

569

Devine, J.R., Holmes, M.R.J., 1963. Field experiments on the value of urea as a fertilizer for

570 barley, sugar beet, potatoes, winter wheat and grassland in Great Britain. J. Agri. Sci. 61,391-

571 396.

572

573 Dobbie, K.E., McTaggart, I.P., Smith, K.A., 1999. Nitrous oxide emissions from intensive

574 agricultural systems: variations between crops and seasons, key driving variables and mean 575 emission factors. J. Geophys. Res.104, 26891-26899.

576 
Dobbie, K., Smith, K. 2003a. Impact of different forms of $\mathrm{N}$ fertilizer on $\mathrm{N}_{2} \mathrm{O}$ emissions from

580 Dobbie, K.E., Smith, K.A., 2003b. Nitrous oxide emission factors for agricultural soils in

581 Great Britain: the impact of soil water filled pore space and other controlling variables. Glob.

582 Change Biol. 9, 204-218.

583

584 Duffy, P., Hanley, E., Black, K., Hyde. B., Ponzi, J., Alam, S. Ireland National Inventory

585 Report 2015, Greenhouse Gas Emissions 1990 - 2013. Reported to the United Nations

586 Framework Convention on Climate Change. Environmental Protection Agency, Johnstown

587 Castle, Co.Wexford, Ireland.

588

589 Ellison, S. L., Farrant, T. J., Barwick, V. 2009. Practical statistics for the analytical scientist:

590 a bench guide, R. Soc. Chem.

591

592 EPA - Environmental Protection Agency, 2013. Irealnds Greenhouse Gas Emission

593 Projections

2012-2030.

594 https://www.epa.ie/pubs/reports/air/airemissions/EPA_GHG_Emission_Proj_pub_2013_FIN

$595 \quad$ AL.pdf (date accessed 31.03.2016)

596

597 European Commission (EC), 2014. Communication from the Commission to the European

598 Parliament, the Council, the European Economic and Social Committee and the Committee

599 of the regions - A policy framework for climate and energy in the period from 2020 to 2030.

600 http://eur-lex.europa.eu/legal-content/EN/TXT/PDF/?uri=CELEX:52014DC0015\&from=EN

601 (date accessed 16.04.2016). 
603 Focht, D.D., Stolzy, L.H., Meek, B.D., 1979. Sequential reduction of nitrate and nitrous oxide 604 under field conditions as brought about by organic amendments and irrigation management. 605 Soil Biol. Biochem. 11,37-46.

606

607 Forrestal, P., Harty, M., Carolan, R., Lanigan, G., Watson, C., Laughlin, R., Mcneill, G., 608 Chambers, B. \& Richards, K. 2015. Ammonia emissions from urea, stabilized urea and 609 calcium ammonium nitrate: insights into loss abatement in temperate grassland. Soil Use 610 Manag. (accepted for publication November 2015).

611

612 Franzen, D., Goos, R.J., Norman, R.J., Walker, T.W., Roberts, T.L., Slaton, N.A., Endres, G., 613 Ashley, R., Staricka, J., Lukach, J., 2011. Field and laboratory studies comparing

614 Nutrisphere-nitrogen urea with urea in North Dakota, Arkansas, and Mississippi. J. Plant 615 Nutr. 34,1198-1222.

616

617 Gately, T.F., 1994. A note on urea versus calcium ammonium nitrate for winter wheat. Irish 618 J. Agri. Food Res. 33,193-196.

619

620 Gilsanz, C., Báez, D., Misselbrook, T.H., Dhanoa, M.S., Cárdenas, L.M., 2016. Development 621 of emission factors and efficiency of two nitrification inhibitors, DCD and DMPP. Agri. 622 Ecosyst. Environ. 216, 1-8.

624 Goos, R.J., 2013. A Comparison of a Maleic-Itaconic Polymer and-(-butyl) Thiophosphoric 625 Triamide as Urease Inhibitors. Soil Sci. Soc. Am. J. 77,1418-1423.

626 
627 Harty, M.A., Forrestal, P.J., Watson, C.J., McGeough, Carolan, R., Elliot, C., Laughlin, R.J., 628 Richards, K.G., Lanigan, G.J., 2016 Sci. Total Environ. (accepted for publication April 2016)

629

630 Hinton, N.J., Cloy, J.M., Bell, M.J., Chadwick, D.R., Topp, C.F.E., Rees, R.M., 2015.

631 Managing fertiliser nitrogen to reduce nitrous oxide emissions and emission intensities from a

632 cultivated Cambisol in Scotland. Geoderma Reg. 4,55-65.

633

634 Hoben, J.P., Gehl, R.J., Millar, N., Grace, P.R., Robertson, G.P., 2011. Nonlinear nitrous

635

oxide $\left(\mathrm{N}_{2} \mathrm{O}\right)$ response to nitrogen fertilizer in on-farm corn crops of the US Midwest. Glob.

636 Change Biol. 17,1140-1152.

637

638 Hyde, B.P., Hawkins, M.J., Fanning, A.F., Noonan, D., Ryan, M., O’toole, P., Carton, O.T., 639 2006. Nitrous oxide emissions from a fertilized and grazed grassland in the South East of 640 Ireland. Nutr. Cycl. Agroecosyst.75,187-200.

641

642 IPCC - Intergovernmental Panel on Climate Change 2014. Hartmann, D.L., A.M.G. Klein 643 Tank, M. Rusticucci, L.V. Alexander, S. Brönnimann, Y. Charabi, F.J. Dentener, E.J. 644 Dlugokencky, D.R. Easterling, A. Kaplan, B.J. Soden, P.W. Thorne, M. Wild and P.M. Zhai, 645 2013: Observations: Atmosphere and Surface. In: Climate Change 2013: The Physical 646 Science Basis. Contribution of Working Group I to the Fifth Assessment Report of the 647 Intergovernmental Panel on Climate Change [Stocker, T.F., D. Qin, G.-K. Plattner, M. 648 Tignor, S.K. Allen, J. Boschung, A. Nauels, Y. Xia, V. Bex and P.M. Midgley (eds.)]. 649 Cambridge University Press, Cambridge, United Kingdom and New York, NY, USA. 650 
651 IPCC 2006. $\mathrm{N}_{2} \mathrm{O}$ emissions from managed soils, and $\mathrm{CO}_{2}$ emissions from lime and urea 652 application. In: 2006 IPCC Guidelines for National Greenhouse Gas Inventories, Prepared by 653 the National Greenhouse Gas Inventories Programme, Eggleston H.S., Buendia L., Miwa K., 654 Ngara T. and Tanabe K. (eds). Published: IGES, Japan.

655

656 Keeney, D.R., Nelson, D.W., 1982. Nitrogen - Inorganic forms. Page, A.L., Baker, D.E., 657 Ellis, R., Keeney, D.R., Miller, R.H., Rhoades, J.D. (Eds.). Methods of Soil Analysis. Part 2. 658 Chemical and Microbiological Properties. $2^{\text {nd }}$ ed. ASA and SSSA, Madison, Wisconsin, 643659698.

660

661 Kool, D.M., Dolfing, J., Wrage, N., Van Groenigen, J.W., 2011. Nitrifier denitrification as a 662 distinct and significant source of nitrous oxide from soil. Soil Biol. Biochem. 43,174-178.

663

664 Lesschen, J.P., Velthof, G.L., de Vries, W., Kros, J., 2011. Differentiation of nitrous oxide 665 emission factors for agricultural soils. Environ. Pollut. 159, 3215-3222.

666

667 Li, D., Lanigan, G., Humphreys J. (2011) Measured and simulated $\mathrm{N}_{2} \mathrm{O}$ emissions from 668 ryegrass and ryegrass/clover swards in a Moist Temperate Climate. Plos-One 6(10): e26176. doi 10.1371/journal.pone.0026176

670

671 Louro, A., Báez, D.,García, M.I., Cárdenas, L. (2015). Nitrous oxide emissions from forage 672 maize production on a Humic Cambisol fertilized with mineral fertilizer or slurries in Galicia, 673 Spain. Geoderma Reg. 5, 54-63.

674 
675 McSwiney, C.P., Robertson, G.P., 2005. Nonlinear response of $\mathrm{N}_{2} \mathrm{O}$ flux to incremental

676 fertilizer addition in a continuous maize (Zea mays L.) cropping system. Glob. Change Biol.

$677 \quad 11,1712-1719$.

678

679 Mctaggart, I. P., Clayton, H., Parker, J., Swan, L., Smith, K. A. 1997. Nitrous oxide 680 emissions from grassland and spring barley, following $\mathrm{N}$ fertiliser application with and 681 without nitrification inhibitors. Biol. Fert. Soils, 25, 261-268.

682

683 Mulvaney, R.L., 1996. Nitrogen - inorganic forms. In: Sparks, D.L., Page, A.L., Helmke, 684 P.A., Loeppert, R.H., Soltanpour, P.N., Tabatabai, M.A., Johnston, C.T., Sumner, M.E. 685 (Eds.). Methods of Soil Analysis. Part 3 Chemical Methods. SSSA, Madison, Wisconsin, pp. $686 \quad 1123-1184$.

687

688

Myhre, G., D. Shindell, F.-M. Bréon, W. Collins, J. Fuglestvedt, J. Huang, D. Koch, J.-F. 689 Lamarque, D. Lee, B. Mendoza, T. Nakajima, A. Robock, G. Stephens, T. Takemura and H. 690 Zhang, 2013: Anthropogenic and Natural Radiative Forcing. In: Climate Change 2013: The 691 Physical Science Basis. Contribution of Working Group I to the Fifth Assessment Report of 692 the Intergovernmental Panel on Climate Change [Stocker, T.F., D. Qin, G.-K. Plattner, M. 693 Tignor, S.K. Allen, J. Boschung, A. Nauels, Y. Xia, V. Bex and P.M. Midgley (eds.)]. 694 Cambridge University Press, Cambridge, United Kingdom and New York, NY, USA.

695

696 Pal, P., McMillan, A.M., Saggar, S., 2016. Pathways of dicyandiamide uptake in pasture 697 plants: a laboratory study. Biol.Fert. Soils. 1-8.

698 
699 Rafique, R., Hennessy, D., Kiely, G., 2011. Nitrous oxide emission from grazed grassland 700 under different management systems. Ecosyst. 14,563-582.

701

702 Ravishankara, A., Daniel, J. S., Portmann, R. W. 2009. Nitrous oxide $\left(\mathrm{N}_{2} \mathrm{O}\right)$ : the dominant 703 ozone-depleting substance emitted in the 21 st century. Science. 326, 123-125.

704

Reay, D. S., Davidson, E. A., Smith, K. A., Smith, P., Melillo, J. M., Dentener, F. \& Crutzen, P. J. 2012. Global agriculture and nitrous oxide emissions. Nat. Climate Change. 2, 410-416.

Smith, K.A., Clayton, H., McTaggart, I.P., Thomson, P.E., Arah, J.R.M., Scott, A., Goulding, K.W.T., Monteith, J.L., Phillips, V.R., 1995. The Measurement of Nitrous Oxide Emissions from Soil by Using Chambers [and Discussion]. Philos. Trans. R. Soc. L. Math. Phys.

711 Engineering Sci. 351,327-338.

712

713 Smith, K.A., Dobbie, K.E., Thorman, R., Watson, C.J., Chadwick, D.R., Yamulki, S., Ball,

714 B.C., 2012. The effect of $\mathrm{N}$ fertiliser forms on nitrous oxide emissions from UK arable land 715 and grassland. Nutr. Cycl. Agroecosyst. 93, 127-149.

717 Stehfest, E., Bouwman, L., 2006. $\mathrm{N}_{2} \mathrm{O}$ and $\mathrm{NO}$ emission from agricultural fields and soils 718 under natural vegetation: summarising available measurement data and modelling of global 719 environmental emissions. Nutr. Cycl. Agroecosyst. 74, 207-228. 
721 Teagasc, 2015. The Spring Barley Guide. Crops, Environment and Land-Use Programme,

722 Teagasc. http://tnet.teagasc.net/crops/ (date accessed 31.03.2016).

723

724 U.S. EPA, 2012. Global Anthropogenic Non-CO2 Greenhouse Gas Emissions: 1990-2030

725 (EPA-R-12-006). Office of Atmospheric Programs, Climate Change Division, U.S.

726 Environmental Protection Agency, 1200 Pennsylvancia Avenue, NW, Washington, DC $727 \quad 20460$, pp 1-188.

728

729 U.S. EPA 2015. Greenhouse Gases. In: Climate Change Indicators in the Unites States.

730 http://www3.epa.gov/climatechange/science/indicators/ghg/. (Date accessed 18.01.2016)

731

732 Van der Weerden, T.J., Jarvis, S.C., 1997. Ammonia emission factors for N fertilizers applied 733 to two contrasting grassland soils. Environ. Pollut. 95,205-211.

734

735 Watson, C. J., Laughlin, R. J., Mcgeough, K. L., 2009. Modification of nitrogen fertilisers

736 using inhibitors: opportunities and potentials for improving nitrogen use efficiency. Proc. Int.

737 Fert. Soc.65,1-40. 